\title{
PENGARUH NON PERFORMING LOAN DAN DANA PIHAK KETIGA TERHADAP KINERJA KEUANGAN DENGAN E- PAYMENT SEBAGAI VARIABEL MODERASI
}

\author{
${ }^{1}$ Dessy Akhirana, ${ }^{2}$ Djauhar Edi Purnomo, ${ }^{3}$ Tutut Dwi Andayani \\ 1,2,3 Program Studi Akuntansi FEB UMPP \\ dwiandayani583@gmail.com
}

\begin{abstract}
This study was conducted to determine and analyze the effect of NonPerforming Loans and Third Party Funds on ROA, and to determine the moderating effet of the E-payment variable on the effect of Non-Performing Loans and Third Party Funds on ROA, in banking companies. The independent variables used in this study were NPL and Third Party Funds; the dependent variable was ROA; and the moderating variable was E-payment. This srudy was quantittative study using a population of 43 Conventional Commercial Banks in Indonesia in the period of 20192020. The sampling technique used was a purposive samplinng method so thata sample of 28 conventional commercial banks in Indonesia in 2019-2020 was obtained, resulting to the total sample of 56 banking companies.

The data analysis technique used in this research was Moderated Regression Analysis and the hypotheses were tested by using SPSS 16.0. The results of the analysis revealed that (1) NPL had a significant negative effect on ROA (2) Third Party Funds had no significant effect on ROA (3) E-payment was not able to moderate or weaken the effect of Non-Performing Loans on Return On Assets and (4) E-payment was able to strengthen Third Party Fund on Return On Assets.
\end{abstract}

Keywords : Non Performing Loan, Third Party Funds, E-PaymenT, Return On Assets

\section{PENDAHULUAN}

Perkembangan sektor keuangan dengan baik dapat memperkuat perekonomian negara. Perkembangan sector keuangan dapat dilihat dari kemampuannya untuk menyediakan dana cadangan yang menyukupi untuk keperluan investasi pembangunan ataupun dalam mencegah terjadinya permasalahan seperti pembiayaan inflasi dan dampak yang disebabkan karena defisit keuangan (Dornbusch dan Reynoso, 1989:204). Sektor keuangan harus memiliki fungsi dan peran dengan baik untuk mendorong tercapainya penyaluran aset yang terkumpul secara efisien untuk penduduk yang memperlukan aset dalam pengeluaran kegiatan perekonominya.

Peran penting industri sektor perbankan untuk mendukung semua kegiatan perekonomian dalam melakukan intermediasi dengan membagi aset dari anggota yang mempunyai kelebihan dana kepada anggota yang kekurangan dana. Pembagian dana kepada pihak yang kekurangan dana 
merupakan strategi dalam perekonomian yang telah diatur dalam Otoritas Jasa Keuangan (OJK) dan Bank Indonesia (BI). Proses penyaluran kredit adalah suatu usaha untuk mendorong terjadinya kegiatan usaha bank yang disebabkan oleh kegiatan bank untuk menjadi perantara keuangan (financial intermediaries).

Non Performing Loan (NPL) adalah merupakan salah satu indikator kesehatan aset bank. NPL mampu memberikan sebuah penilaian terdadap keadaan permodalam, rentabilitas, risiko kredit, risiko pasar hingga likuiditas. Apabila rasio NPL bermasalah tentunya akan berdampak pada penyaluran kredit diperiode sebelumnya. Sehingga dapat mempengaruhi profitabilitas perusahaan. Untuk mendapatkan keuntungan yang besar, maka bank perlu menyesuaikan berapa besar kredit yang dapat disalurkan. Menghimpun dana dari Dana Pihak Kertiga (DPK) merupakan cara bagi bank agar dapat untuk melancarkan penyaluran kredit bagi masyaraka. Dengan adanya Dana Pihak Ketiga yang terkumpul dari nasabah dapat membuka ruang bagi perbankan agar dapat meneruskan dananya untuk nasabah yang memperlukan pinjaman uang yang besar.

Statistik Perbankan Indonesia memperlihatkan kredit bank meningkat sangat rendah dari Rp 5.251,85 triliun pada bulan Agustus 2019 diperoleh Rp 5.286,41 triliun pada bulan Agustus 2020 atau hanya 0,66\%, turun hingga 1,17\% bulan Juli 2020. NPL Gross pada April 2021 tercatat $3,22 \%$, sedangkan pada bulan Maret tercatat 3,18\%. Sedangkan NPL Net tercatat $1,06 \%$ pada April 2021, dan 1,02\% pada bulan Maret. Hal ini mengindikasikan adanya kenaikan. Kenaikan NPL mengindikasikan adanya kenaikan kredit bermasalah, dimana hal tersebut juga akan mempengaruhi kinerja perusahaan. Dana pihak ketiga (DPK) meningkat lebih tinggi dari Rp 5.547,99 triliun menjadi Rp 5.191,91 triliun atau 11,61\%, naik dari $8,51 \%$ dari bulan lalu.

Perkembangan teknologi informasi memiliki perubahan salah satunya pada alat pembayaran, diera digital banking 4.0 merupakan kegiatan transaksi secara digital dimana pembayaran dapat dilakukan secara non tunai (non cash) dibandingkan secara tunai (cash based). Transformasi pembayaran elektronik terus berkembang mengikuti kebutuhan nasabah. Trend penggunaan e-payment semakin meningkat, hal ini bisa dilihat dari table berikut.

Tabel 1.1 Data Penggunaan E-Payment

\begin{tabular}{|c|l|c|c|c|}
\hline \multirow{2}{*}{ No } & \multirow{2}{*}{$\begin{array}{c}\text { Layanan E- } \\
\text { payment }\end{array}$} & \multicolumn{2}{|c|}{ Tahun } & \\
\cline { 3 - 5 } & $\mathbf{2 0 1 9}$ & $\mathbf{2 0 2 0}$ & Growth \\
\hline 1 & ATM & 2,322 & 2,020 & $-13,0 \%$ \\
\hline 2 & Internet Banking & 10,701 & 11,308 & $5,7 \%$ \\
\hline 3 & Mobile Banking & 2,089 & 2,693 & $28,9 \%$ \\
\hline 4 & QRIS & 400 & 1,200 & $17,34 \%$ \\
\hline
\end{tabular}

Sumber : Bank Indonesia 
Dari tabel diatas sapat diinformasikan bahwa perbankan di Indonesia sudah banyak yang menyediakan layanan E-payment. Layanan Epayment tersebut antara lain berupa APMK, Internet Banking, Mobile Banking dan Quick Response Code Indonesia Standar QRIS. Terlihat bahwa penggunakan layanan E-payment tahun 2019 sampai dengan tahun 2020 mengalami peningkatan khususnya pada komponen layanan Internet banking, Mobile banking dan QRIS disetiap tahunnya. Peningkatan ini seiring perkembangan sikap nasabah dan kebutuhan nasabah yang sebagian besar berminat menggunakan pembayaran elektronik pada saat wabah covid-19 dalam rangka menghindari kontak secara fisik dalam melakukan transaksi. Kenyamanan, kemudahan dan keamanan dalam melakukan transaksi merupakan tujuan utama bagi kebutuhan masyarakan dalam meningkatkan perkembangan teknologi. Perubahan perkembangan teknologi tidak dapat dipungkiri sehingga perbankan dituntut untuk menarik minat masyarakat dengan mengembangkan inovasi-inovasi produk dan layanan di sektor perbankan.

Semakin meningkatnya teknologi keuangan dibidang digital yang memiliki pengaruh bagi profitabilitas perbankan dalam jangka panjang. profitabilitas yang digunakan merupakan pencapaian pengembalian Asset Atau Return On Assets (ROA) yang diprosikan sebagai variabel dependen merupakan kegiatan yang dapat mendapatkan income. Memiliki pengaruh yang penting bagi perbankan agar tetap konsisten melindungi kinerjanya dengan baik, terutama untuk melindungi dan mempertahankan tingkat profitabilitas yang tinggi. Dengan adanya layanan E-payment diharapkan dapat memperkuat hubungan NPL dan DPK dalam meningkatkan profitabilitas, layanan e-payment di era pandemic covid 19 ini untuk menyatukan langkah antara pelaku proses digitalisasi dalam tatanan kehidupan perekonomian agar mempunyai kontribusi rill untuk mempercepat perbaikan perekonomian saat ini.

Berdasarkan uraian diatas maka penelitian ini bertujuan untuk mengetahui Pengaruh Non Performing Loan (NPL) dan Dana Pihak Ketiga (DPK) Terhadap Kinerja Keuangan Dengan E-Payment Sebagai Variabel Moderasi (Pada Perbankan Yang Terdaftar Di Bursa Efek Indonesia Periode 2019 - 2020)".

\section{TINJAUAN PUSTAKA}

\section{Teori Sinyal (Signalling Theory)}

Signalling Theory atau teori sinyal merupakan sinyal suatu perusahaan yang memiliki keinginan untuk memberikan informasi yang berkaitan dengan laporan keuangan kepada pihak luar. Dorongan perusahaan untuk memberikan informasi yang terdapat asimetri informasi mengenai perusahaan dan pihak luar karena perusahaan mengetahui lebih banyak mengenai perusahaan dan prospek yang akan datang daripada pihak luar (investor, kreditor). Salah satu cara untuk mengurangi informasi asimetri adalah dengan memberikan sinyal pada pihak luar, salah satunya 
berupa informasi keuangan yang dapat dipercaya dan akan mengurangi ketidakpastian mengenai prospek perusahaan yang akan datang.

Non Performing Loan adalah sebuah alat yang digunakan mensurvei kapasitas tingkat baik buruknya kinerja perbankan. Non Performing Loan (NPL) tinggi menunjukkan suatu kondisi organisasi yang buruk namun jika Non Performing Loan (NPL) turun menunjukkan organisasi yang memiliki kondisi baik. Begitu pula dengan Dana Pihak Ketiga (DPK), apabila DPK meningkatan maka akan mempengaruh keuntungan bank. Profitabilitas yang tinggi menunjukkan kemungkinan organisasi dapat diterima, penanam saham selalu memberikan positif sinyal agar kinerja mengalami peningkatan. Sehingga investor akan tertarik untuk menempatkan asetnya berupa saham atau surat berharga. Permintaan saham yang meningkat membuat peningkatan pada harga saham, dan minat nasabah dalam menggunakan layanan berbasis digital juga ikut meningkat.

\section{Pembayaran Secara Elektronik (E-Payment)}

Electronic payment (E-payment) adalah merupakan model pembayaran yang memudahkan dan menawarkan kenyamanan kepada penggunanya dalam melakukan transaksi pembayaran. Transaksi ini dilakukan secara online dengan memanfaatkan internet, tanpa harus bertemu atau datang jauh-jauh untuk menemui penjual. Transaksi keuangan melalui jaringan perangkat electoronic menurut Wahyu (2005:1) berguna untuk membantu kegiatan e-commerce dalam memperoleh pendapatan bagi kegiatan komersial lebih mengembangkan layanan untuk nasabah, pemngembangan perubahan jasa perbankan, menghemat kesempatan dan produktivitas, kegiatan untuk pengeluarkan dananya memungkinkan dapat terjadi diaman pun, kapan pun,, menggunakan sistem yang berbeda ataupun tidak ada batasnya. Layanan e-pyament berguna untuk keperluan seperti Payment Media Bank (ATM, phone banking, internet banking, mobile banking).

Return on Asset (ROA)

Return On Asset (ROA) adalah membandingkan antara laba bersih sebelum pajak dengan total aset pada bank. Rasio ini dapat memperlihatkan tingkat profitabilitas suatu bank disebabkan untuk mendeskripsikan kinerja dari manajemen dalam menghasilkan keuntungan dalam menggunakan sumber dananya (Rauf, et.al, 2014). Semakin besar Return On Assets (ROA) suatu bank maka semakin besar keuntungan bank, semakin baik pula posisi bank dari segi penggunaan asset. ROA adalah indikator yang akan menunjukkan bahwa apabila rasio ini meningkat, maka aset bank telah digunakan dengan optimal untuk memperoleh pendapatan.

\section{Non Performing Loan (NPL)}

Non Performing Loan (NPL) atau kredit bermasalah adalah kondisi pihak lain yang belum dapat membayar beberapa ataupun seluruh hutangnya kepada bank yang sudah dijanjikan Mudrajat Kuncoro (2002: 
462). Sedangkan menurut (Dendawijaya, 2009:81), Non Performing Loan (NPL) merupakan rasio untuk mengukur kemampuan manajemen bank untuk mengatasi kredit bermasalah yang diberikan oleh bank. Risiko kredit suatu bank merupakan salah satu risiko yang diterima dari usaha atau kegiatan perbankan yang mengakibatkan tidak lunasnya kredit yang diberikan bank kepada debitur.

\section{Dana Pihak Ketiga (DPK)}

Menurut Peraturan Bank Indonesia No 10/19/PBI / 2008 Dana Pihak Ketiga adalah keharusan perbankan terhadap nasabahnya secara umum dananya dikumpulkan oleh perbankan dari nasabah yang menggunakan asetnya untuk pendanaan operasional bank melalui penyaluran kredit. Dana Pihak ketiga sangatlah penting bagi bank dalam menghimpun dana, karena pada dasarnya untuk kepentingan usahanya bank menghimpun dana dari bank itu sendiri, dana yang berasal dari pihak lain dan dana yang berasal dari masyarakat yang berupa tabungan, deposit, serta sumber dana lainnya.

\section{Kerangka Konseptual}

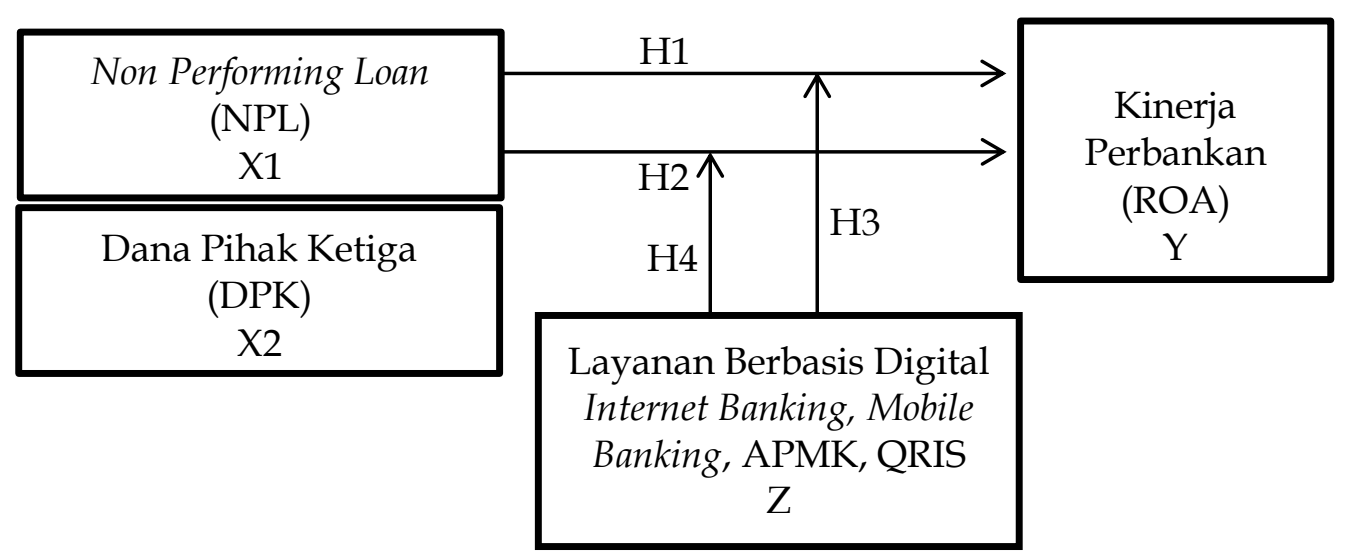

Gambar 1

\section{Hipotesis}

\section{Kerangka Konseptual}

H1 : NPL berpengaruh terhadap Return On Assets (ROA)

H2 : DPK berpengaruh terhadap Return On Assets (ROA)

$\mathrm{H} 3$ : E-payment berpengaruh dalam memoderasi hubungan antara NPL terhadap ROA

H4 : E-payment berpengaruh dalam memoderasi hubungan antara DPK terhadap ROA

\section{METODE PENELITIAN}

\section{Populasi dan Sampel}

Penelitian ini merupakan penelitian kuantitatif. Populasi yang digunakan dalam penelitian ini adalah Bank Umum Konvensional yang ada di Bursa Efek Indonesia (BEI) pada periode 2019 - 2020. Teknik 
pengambilan sampel dalam penelitian ini diperoleh dengan mengguankan metode purposive sampling. Kriteria-kriterianya adalah sebagai berikut:

1. Sampel merupakan perbankan terdapat di Bursa Efek Indonesia (BEI) periode 2019-2020.

2. Perusahaan menerbitkan laporan keuangan periode di Bursa Efek Indonesia (BEI) periode 2019-2020.

3. Perusahaan yang terdapat di Bursa Efek Indonesia (BEI) yang sudah menggunakan E-banking.

4. Perusahaan terdapat di Bursa Efek Indonesia (BEI) yang tidak delisting atau sahamnya masih tercatat di BEI sampai tahu 2020.

\section{Variabel dan Definsi Operasional Variabel Variabel Independen}

Variabel Independen merupakan variabel yang mempengaruhi atau menjadi sebab perubahannya atau timbulnya variabel dependen (Sugiyono, 2014:38).

1. Non performing loan (NPL)

Non Performing Loan (NPL) merupakan rasio untuk mengukur kemampuan manajemen bank untuk mengatasi kredit bermasalah karena nasabah tidak sanggup membayar sebagian atau seluruh kewajibannya.

Menurut Slamet Riyadi, 2015 Non performing loan (NPL) dapat diukur dengan rumus sebagai berikut :

$$
\mathrm{NPL}=\frac{\text { Total Kredit Bermasalah }}{\text { Total Kredit }} \times 100 \%
$$

2. Dana Pihak Ketiga (DPK)

Dana Pihak Ketiga (DPK) merupakan kewajiban bank kepada penduduk dalam rupiah dan valutan asing. Umumnya dana yang dihimpun oleh perbankan dari nasabah akan digunakan untuk pendanaan aktivitas sektor riil melalui penyaluran kredit. Dana Pihak Ketiga terdiri dari Demand Deposit (Giro), Saving Deposit (Tabungan) dan Time Deposit (Deposit). Menurut Peraturan Bank Indonesia No 10/19/PBI /2008 dapat diukur dengan rumus sebagai berikut :

Dana Pihak Ketiga $=$ Giro + Tabungan + Deposit

\section{Variabel Dependen}

Variabel dependen adalah variabel yang dipengaruhi atau menjadi akibat karena adanya variabel independen (Sugiyono, 2014:38). Variabel dependen penelitian ini adalah kinerja bank. Untuk mengukur kinerja bank peneliti menggunakan pertumbuhan laba sebagai parameternya.

Return on Assets (ROA)

Return On Asset (ROA) merupakan rasio yang memandingkan antara laba bersih sebelum pajak dengan total aset suatu bank. Rasio ini dapat menunjukkan profitabilitas suatu bank karena dapat 
mendeskripsikan kinerja dari manajemen dalam menghasilkan laba dalam menggunakan asetnya (Rauf, et.al., 2014). Menurut Slamet Riyadi,2015 Return on Asset (ROA) dapat diukur dengan rumus sebagai berikut:

$$
\mathrm{ROA}=\frac{\text { Laba Sebelum Pajak }}{\text { Total Aset }} \times 100 \%
$$

\section{Variabel Moderating}

Variabel moderating adalah variabel yang dapat memperkuat atau memperlemah hubungan langusng antara variabel independen dengan variabel dependen. Variabel moderating adalah variabel yang mempunyai pengaruh terhadap sifat atau arah hubungan antar variabel. Sifat atau arah hubungan antara variabel-variabel independen dengan variabel-variabel dependen kemungkinan positif atau negatif tergantung pada variabel moderating, oleh karena itu variabel moderating dinamakan pula sebagai contigency variabel.

Variabel layanan pembayaran secara elektronik (E-Payment) yang di kategori menjadi empat yaitu : Internet Banking, Mobile Banking, Alat Pembayaran Menggunakan Kartu (APMK), dan Quick Response Code Indonesia Standar (QRIS). Untuk mengkuantitatifkan data kualitatif masingmasing data layanan E-payment dijumlahkan, hasil dari perhitungan tersebut dijadikan dasar untuk mengindeks.

\section{Teknik Pengumpulan dan Analisis Data}

Teknik pengumpulan data dalam penelitian ini dilakukan dengan metode dokumentasi. Data diperoleh dari media internet dan beberapa data yang telah dipublikasikan di www.idx.co.id, www.bi.go.id, www.ojk.go.id.

Data yang digunakan dalam penelitian ini merupakan data sekunder. Data sekunder dalam penelitian ini diperoleh dari laporan keuangan yang bersumber langsung dari bank umum yang dijadikan sampel penelitian periode 2019-2020 dan data yang dipublikasikan oleh Bank Indonesia serta Badan Pusat Statistik.

Teknik analisis yang digunakan dalam penelitian ini menggunakan Moderating Regression Analysis. Pengolahan data dengan menggunakan SPSS 16.0.

\section{HASIL DAN PEMBAHASAN Deskripsi Objek Penelitian}

Penelitian ini menggunakan 4 variabel akan digunakan sebagai bahan analisis, Keempat variabel kemudian dikelompokkan menjadi tiga kelompok, variabel pertama yaitu Kinerja Keuangan sebagai variabel dependen, sedangkan dua variabel lainya yaitu variabel Non Performing Loan (NPL) dan Dana Pihak Ketiga (DPK) merupakan variable independen, dan satu variable yaitu E-payment sebagai variabel moderasi. Dari perolehan data didapatkan 56 sampel. 
Tabel 4.2 Kriteria Sampel Penelitian

\begin{tabular}{|c|l|c|}
\hline No & \multicolumn{1}{|c|}{ Kriteria } & Sebanyak \\
\hline 1 & Perbankan berada di BEI periode 2019-2020 & 43 \\
\hline 2 & $\begin{array}{l}\text { Tidak menyampaikan laporan keuangan } \\
\text { periode 2019-2020 }\end{array}$ & $(15)$ \\
\hline 3 & $\begin{array}{l}\text { Perabankan yang tidak memiliki layanan E- } \\
\text { payment }\end{array}$ & 0 \\
\hline 4 & Delisting tahun 2020 & 0 \\
\hline Jumlah sampel akhir yang memenuhi kriteria & 28 \\
\hline \multicolumn{2}{|l|}{ Total 28 x 2 } & 56 \\
\hline
\end{tabular}

Sumber : Data diolah peneliti

Hasil Analisis Penelitian

Analisis Deskriptif

Table 4.2

Descriptive Statistics

\begin{tabular}{|l|r|r|r|r|r|}
\hline & $\mathrm{N}$ & $\begin{array}{r}\text { Minimu } \\
\mathrm{m}\end{array}$ & $\begin{array}{r}\text { Maximu } \\
\mathrm{m}\end{array}$ & Mean & $\begin{array}{c}\text { Std. } \\
\text { Deviation }\end{array}$ \\
\hline ROA & 56 & $-3,36$ & 5,51 & 1,2382 & 1,43433 \\
NPL & 56 & 0,00 & 10,16 & 3,1563 & 1,88567 \\
LN_DPK & 56 & 2,20 & 9,19 & 5,5793 & 1,90924 \\
E-Payment & 56 & 0,00 & 4,00 & 3,0893 & 1,11644 \\
Valid N & 56 & & & & \\
(listwise) & & & & & \\
\hline
\end{tabular}

Sumber : Data Sekunder yang diolah

\section{Uji Asumsi Klasik}

\section{Uji Normalitas}

Uji normalitas residual menggunakan uji Kolmogorov-SmirnovI. Dari hasil uji ini diperoleh nilai signifikansi sebesar 0,720 $(0,720>0,05$, yang berarti berdistribuso normal, sehingga asumsinya terpenuhi.

\section{Uji Multikolinearitas}

Hasil uji multikolinieritas menunjukkan bahwa nilai ditabel tolerance variabel Performing Loan (NPL) sebesar 0,954, variabel Dana Pihak Ketiga (DPK) adalah diperoleh 0,730, variabel E-Payment adalah sebesar 0,726 dari variabel penelitian melebihi 0,10. Sedangkan pada kolom VIF didapatkan tingkat variable Non Performing Loan (NPL) adalah sejumlah 1,048, variable Dana Pihak Ketiga (DPK) adalah sejumlah 1,371, variabel $E$ Payment adalah sebesar 1,377. Dapat disimpulkan dimana variable bebas memiliki nila $>10$ yang berati tidak mengalami permasalahan multikolinieritas. 


\section{Uji Autokorelasi}

Hasil uji autokorelasi menggunakan uji Durbin Waston. Nilai uji Durbin Waton sebesar 2,222, dimana nilai tersebut berada diantara nilai dU 1,683 dan nila 4 - dU 2,317 yang dapat diartikan tidak terjadi permasalahan autokorelasi.

\section{Uji Heteroskedastisitas}

Uji heteroskedastisitas terhadap model regresi antara Non Performing Loan (NPL), Dana Pihak Ketiga (DPK) dan E-Payment kepada ROA dengan menggunakan uji Spearman's rho. Hasil uji diperoleh nila korelasi antara Non Performing Loan (NPL) mengunakan Unstandardized Residual dihasilakn nilai signifikansi 0,905, korelasi antara Dana Pihak Ketiga (DPK) dengan Standardized Residual menghasilkan nilai signifikansi 0,909, korelasi antara E-Payment dengan Standardized Residual menghasilkan nilai signifikansi 0,517 karena nilai signifikansi korelasi lebih besar dari 0,05, maka dapat disimpulkan bahwa pada model regresi tidak ditemukan adanya masalah heteroskedastisitas.

\section{Hasil Analisis Regresi}

Hasil analisis regresi berganda diperoleh model persamaan regresi linier seperti : $\mathrm{ROA}=3,098-0,339 \mathrm{NPL}-0,141 \mathrm{DPK}$

Persamaan regresi diatas dapat diinterpretasikan sebagai berikut :

1. Nilai constant sebesar 3,098 artinya jika NPL, DPK bernilai 0 maka Return on asset (ROA) sebesar $30,98 \%$

2. Koefisien regresi untuk NPL sebesar $-0,339$ bertanda negatif. Hal ini berarti setiap perubahan $1 \%$ pada NPL sementara variabel independen lain diasumsikan tetap maka ROA akan turun sebesar 0,339

3. Koefisien regresi untuk DPK sebesar $-0,141$ bertanda negatif. Hal ini berarti setiap perubahan $1 \%$ pada DPK sementara variabel independen lain diasumsikan tetap maka ROA akan turun sebesar 0,141.

\section{Uji Hipotesis secara Parsial}

1. Pengaruh Non Performing Loan (NPL) terhadap Kinerja Perbankan (ROA)

Berdasarkan hasil uji $t$ pada tabel diatas diperoleh $t$ hitung sebesar $-3,000$ dengan probabilitas $0,000<0,10$ maka variabel NPL berpengaruh negatif signifikan terhadap Return On Asset. Sehingga H1 diterima dan H0 ditolak artinya variabel NPL berpengaruh negatif signifikan terhadap Retun On Asset.

\section{Pengaruh Dana Pihak Ketiga (DPK) terhadap Kinerja Perbankan (ROA)}

Berdasarkan pada hasil uji $t$ tersebut diperoleh $t$ hitung sebesar $-1,572$ dengan probabilitas 0,122 > 0,10 maka variabel Dana Pihak Ketiga (DPK) tidak berpengaruh negatif signifikan terhadap Return On Asset (ROA), sehingga $\mathrm{H} 0$ ditolak dan $\mathrm{H} 2$ diterima artinya variabel Dana Pihak Ketiga (DPK) tidak berpengaruh signifikan terhadap Return On Asset (ROA). 


\section{Pengaruh E-Payment dalam moderasi hubungan Non performing loan (NPL) terhadap Kinerja Perbankan (ROA)}

Berdasarkan pada hasil uji $\mathrm{t}$ tersebut diperoleh $\mathrm{t}$ hitung variabel $\mathrm{X} 1 . \mathrm{Z}$ sebesar 0,824 dengan probabilitas 0,414 >0,10. Variabel moderat yang merupakan interaksi antara $\mathrm{X} 1$ dan $\mathrm{Z}$ ternyata tidak signifikan, sehingga dapat disimpulkan bahwa variabel E-payment tidak mempengaruhi hubungan Non Performing Loan (NPL) terhadap Return On Assets (ROA)

4. Pengaruh E-Payment dalam moderasi hubungan Dana Pihak Ketiga (DPK) terhadap Kinerja Perbankan (ROA)

Berdasarkan pada hasil uji $t$ tersebut diperoleh $t$ hitung variabel 1 X2.Z diperoleh uji $t$ hitung sebesar 2,264 dengan probabilitas 0,28 0,10. Variabel moderat yang merupakan interaksi antara X2 dan Z ternyata signifikan, sehingga dapat disimpulkan bahwa variabel e-payment mempengaruhi hubungan Dana Pihak Ketiga (DPK) terhadap Return On Assets (ROA)

\section{Uji secara Simultan}

Berdasarkan tabel diatas nilai $F_{\text {hitung diperoleh 9,525 dengan tingkat }}$ signifikasi 0,000 berarti probabilitas $(0,000)$ lebih kecil dibandingkan taraf signifikan sebesar 0,10 maka dapat simpulkan bahawa Non Performing Loan (NPL) dan Dana Pihak Ketiga (DPK) berpengaruh secara simultan terhadap Return On Asset (ROA).

\section{Koefesien Determinasi}

Hasil koefisien determinasi didapat kan nilai Adjusted $\mathrm{R}$ Square sebesar 0,237 hal tersebut berati bahwa 23,7\% variabel nila perusahaan yang diproposikan dengan ROA dapat dijelaskan oleh Non Performing Loan (NPL) dan Dana Pihak Ketiga (DPK) sisanya sebesar 76,3\% dijelaskan variabel lain diluar model.

\section{Pembahasan Penelitian \\ Pengaruh NPL terhadap ROA}

Hipotesis pertama diperoleh hasil bahwa Non Performing Loan (NPL) berpengaruh negatif signifikan terhadap ROA. Hal ini menunjukkan bahwa dengan NPL yang tinggi menyebabkan semakin tinggi pula biaya yang dikeluarkan oleh bank, dan berdampak juga pada penurunan pendapatan oleh bank yang berasal dari kredit. Apabila NPL yang terjadi disuatu bank bernilai tinggi, maka bisa disebabkan oleh para peminjam kredit yang tidak membayar atau melunasi kreditnya. Sehingga akan mempengaruhi kinerja bank dan mengakibatkan modal bank menurun dan berpotensi mengakibatkan kerugian pada bank akibatnya kinerja bank akan menurun.

Hal ini dapat dilihat ditengah meningkatnya risiko kredit, penyaluran kredit juga semakin terkontraksi dan akhirnya berdampak menurunkan profitabilitas perbankan. Statistik Perbankan Indonesia menunjukkan kredit bank tumbuh sangat gersang dari Rp 5.251,85 triliun per Agustus 2019 
menjadi Rp 5.286,41 triliun. Dimana NPL Gross per Desember 2019 2,50\% mengalami peningkatan per Desember 2020 3,06\%, hal ini dipengaruhi oleh turunnya kemampuan pembayaran debitur dan lemahnya deman kredit baru sebagai akibat pandemi covid-19 yang cukup signifikan berdampak pada penurunan kegiatan maupun pendapatan.

Hasil penelitian ini konsisten dengan hasil penelitian yang dilakukan oleh Willy Kardinal (2021) menunjukkan hasil Non Performing Loan (NPL) berpengaruh negatif dan signifikan terhadap profitabilitas hal ini menunjukkan bahwa variabel NPL yang tinggi menyebabkan semakin tinggi pula biaya yang dikeluarkan oleh bank, dan berdampak pada penurunnya pendapatan oleh bank yang berasal dari kredit. Apabila NPL yang terjadi disuatu bank bernila tinggi, maka bank tersebut mengalami masalah yang dikarenakan oleh para peminjam kredit belum membayar atau melunasi kreditnya.

\section{Pengaruh DPK terhadap ROA}

Hasil hipotesis kedua bahwa Dana Pihak Ketiga (DPK) tidak memiliki pengaruh signifikan terhadap ROA. DPK tidak berpengaruh terhada ROA disebabkan karena ketidakseimbangan antara jumlah sumber dana yang masuk dengan jumlah kredit yang diberikan kepada masyarakat. Semakin tinggi dana pihak ketiga yang terkumpul dibank namun tidak diimbangi dengan penyaluran kredit, maka kemungkinan bank memgalami kerugian atau penurunan profitabilitas sehingga ROA atau efektifitas bank dalam mendapatkan keuntungan ikut menurun, karena pendapatan bunga dari penyaluran kredit kepada debitur tidak mencukupi untuk menutupi biaya bunga yang harus dibayarkan kepada deposan.

Pada tahun 2019 pertumbuhan DPK sedikit mengalami melambat hal ini disebabkan karena terjadi perlambatan DPK pada dua komponen terbesar yaitu giro sebesar Rp. 1.393.013 triliun dan deposit sebesar Rp. 2.441.375 triliun perlambatan ini sejalan dengan penurunan suka bunga giro dan deposit dan banyaknya penarikan dana untuk operasional. Hal ini juga disebabkan oleh likuiditas yang terus melambung tinggi yang menyebabkan bank menjadi terbebani karena harus membayar bunga simpanan kepada masyarakat. Sementara itu, dalam waktu bersamaan, perbankan juga harus melakukan restrukturisasi kredit, salah satu skemanya adalah bunga kredit tidak ditagih atau diturunkan. Perbankan tidak akan kuat bertahan jika terus menerus bayar bunga simpanan, sementara bunga kredit direlaksasi. Apabila bank tidak memupuk profit, dan margin bunga bersih (Net Interest Margin) tipis, maka kinerjanya akan turun.

Hasil penelitian ini konsisten dengan hasil penelitian yang dilakukan oleh Nailal Unlia (2020), pada penelitian ini menunjukkan bahwa Dana Pihak Ketiga tidak berpengaruh terhadap kinerja pada bank umum konvensional di BEI tahun 2014-2018. Hal ini menunjukkan bahwa semakin meningkat dan menurunnya dana pihak ketiga yang dimiliki oleh suatu 
bank, belum tentu mencerminkan laba yang besar yang dimiliki oleh suatu bank tersebut.

\section{Pengaruh E-Payment dalam memoderasi hubungan antara NPL terhadap ROA}

Hasil hipotesis ketiga diperoleh hasil bahwa E-Payment tidak mempengaruhi hubungan Non Performing Loan (NPL) terhadap Return On Assets (ROA). Hal ini disebabkan karena penggunaan layanan yang belum maksimal oleh nasabah mengakibatkan pendapatan yang didapat dari penyediaan layanan belum maksimal, sehingga belum mampu menutupi biaya operasi penyediaan layanan.

Penelitian lain yang dilakukan oleh Alfauzi Firdaus (2019) tentang dipengaruh layanan e-payment terhadap kinerja perbankan Indonesia, hasil penelitian menunjukkan bahwa masing-masing variable merupakan inrernet banking, mobile banking, dan APMK tidak berpengaruh terhadap kinerja perbankan.

\section{Pengaruh E-Payment dalam memoderasi hubungan antara DPL terhadap ROA}

Hipotesis keempat diperoleh hasil bahwa E-Payment berpengaruh dalam memoderasi hubungan antara Dana Pihak Ketiga (DPK) terhadap Return On Assets (ROA). Data menunjukkan adanya peningkatan Dana Pihak Ketiga (DPK) tahun 2020 pada komponen tabungan sebesar Rp. 2.053.575 triliun meningkat dari tahun sebelumnya. Peningkatan ini juga terlihat adanya peningkatan penggunakan layanan $e$ - payment. Dengan adanya peningkatan layanan E-payment dapat meningkatkan kinerja perusahaan sehingga dapat memperoleh laba yang diterima maksimal.

Hasil penelitian ini konsisten dengan hasil penelitian yang dilakukan oleh Siska W (2021) menyebutkan Internet Banking memiliki pengaruh positif dan signifikan kepada kinerja perusahaan Bank komersial memainkan peran besar dalam pertumbuhan dan perkembangan ekonomi setiap negara.

\section{KESIMPULAN DAN SARAN}

\section{Kesimpulan}

Dari hasil penelitian ini dapat disimpulkan sebagai berikut:

1. Non Performing Loan (NPL) memiliki pengaruh signifikan terhadap Return On Assets (ROA). Hal ini terlihat dari hasil uji $\mathrm{t}$, dimana nilai signifikansinya 0,000 .

2. Dana Pihak Ketiga (DPK) tidak memiliki pengaruh signifikan terhadap Return On Assets (ROA). Hal ini terlihat dari nilai signifikansi 0,122 yang berarti diatas 0,10, hal ini menunjukkan bahwa DPL tidak memiliki .

3. E-Payment tidak mempengaruhi hubungan Non Performing Loan (NPL) terhadap Return On Assets (ROA). Hasil ini ditunjukkan dari hasil uji t dengan nilai signifikansi 0,414 . 
4. E-Payment mempengaruhi hubungan Dana Pihak Ketiga (DPK) terhadap Return On Assets (ROA). Dimana hasil uji $t$ menunjukkan nilai signifikansi 0,028 .

\section{Saran}

1. Penelitian berikutnya bisa menambahkan periode penelitian.

2. Penelitian berikutnya dapat menambah variabel independen yang memiliki keterkaitan terhadap kinerja keuangan perbankan misalnya diversifikasi produk perbankan.

\section{REFERENSI}

Alfauzi Firdaus. (2019). Penagaruh Layanan Electronic Payment Terhadap Kinerja Perbankan Indonesia. Fakultas Ekonomi dan Bisnis Universitas Jember.

Dedeh Sri S, Nana S, Ane K. (2018). Analisis Pengaruh Mobile Banking Terhadap Kinerja Perusahaan Sektor Perbankan Yang Tercatat Di Bursa Efek Indonesia. Jurnal Ekonomi Manajemen.

Ghozali, Imam. (2018). Aplikasi Multivariate dengan Program SPSS. Semarang: Penerbit UNDIP.

Lulu Ilmang S. (2020). Pengaruh Sistem Layanan Berbasis Digital E-Payment, Rasio Keuangan, Makro Ekonomi Terhadap Kinerja Perbankan . Skripsi Universitas Islam Negeri Maulana Malik Ibrahim Malang.

Margaretha, Farah. (2015). Dampak Electronik Banking Terhadap Kinerja Perbankan Indonesia. Jurnal Keuangan dan Perbankan Vol. 19 No. 3. September , 514-524.

Naila Unila K. (2020). Pengaruh Pertumbuhan Dana Pihak Ketiga, Pertumbuhan Kredit, Risiko Kredit, Kondisi Ekonomi, Dan Biaya Efesiensi Operasional Terhadap Profitabilitas (Studi Empiris pada Bank Umum Konvensional yang Terdaftar di Bursa Efek Indonesia Periode 2014-2018). Fakultas Ekonomi Dan Bisnis Universitas Muhammadiyah Magelang .

P. Haryoso, Bambang Kusdiasmo. (2017). Capital Edequacy Ratio (CAR) Dan Pihak Ketiga (DPK) Terhadap Return On Assets (ROA) Dengan Penyaluran Kredit sebagai Variabel Intervening.

Riyadi, Slamet. (2015). Banking Assets and Liabiity Management. Jakarta: Lembaga Penerbit Fakultas Ekonomi Universitas Indonesia.

Willy Osvaldo, K. (2021). Pengaruh Non Performing Loan (NPL), Net Interest Margin (NIM), Suku Bunga, Dan Loan To Deposit Ratio (LDR) Terhadap Return On Assets (ROA) Bank Umum Konvensional yang Terdaftar Di Bursa Efek Indonesia (Periode Tahun 2015-2019). Publikasi Riset Mahasiswa Manajemen. 